\title{
Retained Earnings Factor Analysis on Return and Excess Return: A Comparison Study of Retained Earnings-to-Market Equity and Book- to-Market Equity from 2008 - 2018
}

\author{
Muhammad Fahreza ${ }^{1,}$ Eko Rizkianto ${ }^{2 *}$
}

\author{
${ }^{1}$ Universitas Indonesia \\ ${ }^{2}$ Universitas Indonesia \\ *Corresponding author. Email: ekorizki1969@gmail.com
}

\begin{abstract}
The most recent study regarding book-to-market was by Ball (Ball et al., 2020) which based on stocks in the United States. They found that retained earnings gives book-to-market predictive power in explaining and predicting expected return. Then, can the book-to-market phenomenon in Indonesia be explained through the retained earnings factor? This study tries to explain and compare factors between retained earnings and book value of equity in Indonesia. This study uses the Fama-MacBeth regression method and portfolio test using Single Index Model in explaining returns and excess returns to book-to-market and retained earnings-to-market. The results show that the retained earnings-to-market factor can explain average cross section of returns. The portfolio test shows that the retained earnings-to-market factor had a higher excess return and alpha than bookto-market for equally weighted portfolio. Recommendation for future research are testing the retained earnings factor to predict return as individual stocks rather as portfolio.
\end{abstract}

Keywords: Retained Earnings, Book-to-Market, Fama-MacBeth Regression, Single Index Model.

\section{INTRODUCTION}

One of the factors highlighted in the asset pricing model is the firm value factor (HML) that appears in the model created by Eugene Fama and Kenneth French in the Fama French Three Factors model [1]. The value factor is a phenomenon of the book/price strategy, which is a strategy of buying stocks with a high book value of equity/market value of equity (BE/ME) ratio and selling stocks with a low ratio [2]. Initially, research on firm value (in this case represented by price earnings ratio) was a study to prove related to market efficiency or the efficient market hypothesis [3].

The book-to-market phenomenon was also found in Indonesia. Based on data from IHSG top gainers from 2019 at table 1, the book-to-market calculation shows that there are stocks outside of the IPO stocks that have very high return performance. Stocks that have a high book-to-market are indicated by the book-to-market value above 1. Meanwhile, based on IHSG top losers data in 2019, it can be seen that the majority have low book-to-market at the beginning of the year. This can be seen from the book-to-market value of the top losers below 1 . Another thing that can be notice is the trend of top gainers book-to-market ratio at the end of the year tends to be lower than at the beginning of the year, and for the top losers it applies the opposite. It turns out that the book- to-market phenomenon can be found in the stocks of top gainers and top losers in Indonesia.

The level of company value is determined based on the $\mathrm{BE} / \mathrm{ME}$ ratio, which is a combination of book value and market value of equity. Book value is the value that comes from accounting records, while fair value is the value of equity in the market. Equity itself is part of the statement of financial position which shows funding made by investors as well as funds reinvested. The book value of equity itself is divided into three parts, namely contributed capital, retained earnings, and others [4]

By having three general elements in equity, the information contained in the value of equity has different functions. Contributed capital has information to show how much investors contribute to share ownership in the company, retained earnings have information as the company's net profit or loss accumulation over the course of the company, and others have information regarding the company's financial assets that experience changes in value (unrealized gain or loss). As a result of these different elements, the information in equity should have a different effect on the company's stock price. 
Table 1. Top Gainers and Top Losers Book-to-Market Ratio

\begin{tabular}{|c|c|c|c|c|c|c|c|}
\hline \multirow[b]{2}{*}{ Code } & \multirow[b]{2}{*}{ Change \% } & \multicolumn{2}{|c|}{ BE/ME } & \multirow[b]{2}{*}{ Code } & \multirow[b]{2}{*}{ Change \% } & \multicolumn{2}{|c|}{ BE/ME } \\
\hline & & $\begin{array}{c}\text { Early Year } \\
2019\end{array}$ & $\begin{array}{l}\text { End of the } \\
\text { Year } 2019\end{array}$ & & & $\begin{array}{c}\text { Early Year } \\
2019\end{array}$ & $\begin{array}{l}\text { End of the } \\
\text { Year } 2019\end{array}$ \\
\hline SLIS* & $3630,43 \%$ & 0,02 & 0,02 & POOL & $-96,93 \%$ & 0,08 & 1,35 \\
\hline CLAY* & $1877,78 \%$ & 0,03 & 0,02 & FIRE & $-95,79 \%$ & 0,03 & 0,71 \\
\hline ARTO & $1584,78 \%$ & 0,53 & 0,18 & FORZ & $-94,57 \%$ & 0,15 & 2,88 \\
\hline SINI* & $1427,78 \%$ & 0,02 & 0,03 & BOSS & $-92,83 \%$ & 0,06 & 0,80 \\
\hline ITIC* & $1087,21 \%$ & 0,34 & 0,11 & SMRU & $-92,31 \%$ & 0,12 & 1,24 \\
\hline NATO* & $953,40 \%$ & 0,15 & 0,09 & KPAS & $-88,29 \%$ & 0,32 & 2,93 \\
\hline $\mathrm{KJEN}^{*}$ & $919,80 \%$ & 0,05 & 0,06 & POLA & $-88,09 \%$ & 0,07 & 0,47 \\
\hline ARKA* & $785,59 \%$ & 0,003 & 0,03 & KIOS & $-88,08 \%$ & 0,06 & 0,47 \\
\hline POLU* & $733,33 \%$ & 0,22 & 0,09 & COWL & $-88,04 \%$ & 0,55 & 3,78 \\
\hline HRME* & $719,05 \%$ & 0,27 & 0,14 & ANDI & $-87,50 \%$ & 0,07 & 0,56 \\
\hline $\mathrm{PICO}$ & $580,00 \%$ & 2,11 & 0,31 & RODA & $-87,44 \%$ & 0,45 & 3,32 \\
\hline POLL & $534,29 \%$ & 0,19 & 0,02 & INAF & $-86,62 \%$ & 0,02 & 0,19 \\
\hline JAST* & $479,27 \%$ & 0,09 & 0,08 & ARMY & $-84,28 \%$ & 0,44 & 2,65 \\
\hline SFAN* & $471,81 \%$ & 0,20 & 0,13 & TGRA & $-82,50 \%$ & 0,15 & 0,80 \\
\hline DWGL & $438,89 \%$ & $-0,06$ & $-0,01$ & INCF & $-81,88 \%$ & NA & NA \\
\hline
\end{tabular}

*IPO

According to Ball, he had a hypothesis about the predictive power of $\mathrm{BE} / \mathrm{ME}$ that came from retained earnings, one of elements in book value of equity [4]. There are two reasons why Ball create this hypothesis, first is when it is related to market value, earnings have the same factor as expected return, second is the time problem in accounting which reduces the effectiveness of information on bottom-line financial statements such as net income [5][6][7] but the problem disappears when net income is accumulated on retained earnings.

Based on the explanation above, this study aims to determine whether the retained earnings factor can explain the book-to-market factor in predicting expected returns based on the findings of Ball [4]. This research will test the ability of retained earnings to predict return and excess return on stocks listed on Indonesia Stock Exchange. The significance of this research is the consideration of investors in forming a portfolio using a value investing approach.

\section{LITERATURE REVIEW}

\subsection{Ball, Gerakos, Linnainmaa \& Nikolaev (2020)}

Ball et al [4] conducted their research in United States using stock samples of NYSE, AMEX, and NASDAQ. The purpose of this research is to prove the hypothesis related to $\mathrm{BE} / \mathrm{ME}$, which is obtained from the element of retained earnings on book equity and to compare the use of retained earnings-to-market to bookto-market ratios in explaining expected return. This study uses monthly return data, market value of equity data and book-to-market data from July 1964 to June 2017.

Fama-MacBeth's regression and portfolio tests are the method used in this research. The conclusion of this research is that retained earnings-to-market beat bookto-market in predicting returns nonetheless retained earnings only represent $41 \%$ of book equity. Meanwhile contributed capital-to-market does not have the ability to predict return. Furthermore, retained earnings-tomarket is a good proxy for representing earnings yield.

\subsection{Cakici, Chatterjee \& Topyan (2015)}

Cakici et al [8] conducted their research on stocks in China using a sample of shares of companies listed on the Shenzen Stock Exchange. The purpose of this research is to prove that the decomposition of $\mathrm{BE} / \mathrm{ME}$ will increase the predictive ability of the expected return in the traditional regression model. Data samples were taken from January 1996 to December 2012. The data used in this study, which consist of were book-tomarket, change in price per share, change in book equity per share, and change in share outstanding over a 12 
month period. The method used in this research is crosssection regression method.

The general conclusion in this study is that the decomposition of the BE/ME ratio into changes in book equity and price increases the explanatory power of the existing model. The increase in explanatory power comes from changes in book equity, while changes in price do not significantly add to the explanatory power. Besides there is no evidence that the net share issue and momentum are significant estimators.

\subsection{Blackburn \& Cakici (2019)}

Blackburn and Cakici [9] conducted their research on developing countries which are divided into South America, Europe / Middle East / Africa, and Asia groups. The purpose of this research is to determine which factors that have a relationship to book-to-market and return, whether risk factors, overreaction, or tangible / intangible information. This study uses data on stock returns, market capitalization, book-to-market, and net share issues with the sample period from January 1991 to December 2016. The method used is cross-section regression method.

The conclusion in this study is that decomposition of the $\mathrm{BE} / \mathrm{ME}$ component into three parts can improve the model in estimating expected returns. Changes in book value have a more significant impact on predicting expected returns. In addition, tangible information has a significant relationship with expected returns, while intangible information does not. These results were consistent for the three areas studied.

\subsection{Atilgan, Demirtas, Gunaydin \& Kirli (2020)}

Atilgan et al [10] conducted their research in several countries which are divided into four zones, namely zone 1 (America and Canada), zone 2 (Eurozone), zone 3 (Japan), and zone 4 (Asia and Australia). The aim of this study is to determine the origin of the strength of the book-to-market ratio on predicting returns.

This study used data on market equity, risk-free rate, book equity, and dividend payments from 1990 to 2014 . The method used in this study was the cross-section regression method. The conclusion in this study is that changes in firm size do not affect the book-to-market ability to predict returns outside the United States. In addition, the independent variable part of the book-tomarket that cannot be explained by changes in company size actually results in a higher difference in portfolio returns compared to portfolios arranged based on company size.

\section{METHODOLOGY}

\subsection{Data}

Data that collected for this research using a nonfinancial firm stocks listed on Indonesia Stock Exchange from July 2008 to June 2018 from Thomson Reuters. Another samples criteria for this research are must have market value of equity, monthly return, had positive book value of equity and retained earnings, and exclude microcap stocks or $20 \%$ lowest of market capitalization. We used market capitalization as a proxy $\log$ size and market of equity, and common shareholders of equity as proxy for book value of equity. Additional things that was added for portfolio test are using two types of weight (value weighted and equally weighted).

\subsection{Method}

We use two methods to perform hypothesis testing. First, we use Fama-MacBeth regression [11] which has a two-stage regression method, the first stage is a time series regression, and second stage is cross-section regression. In the Fama-MacBeth regression test, we use return portfolio $t$ as the dependent variable, and log size, book-to-market, retained earnings-to-market as the independent variable. The dependent variables, return $t$ was formed into 20 portfolios sorted by size. The model used is as follows:

$$
\begin{aligned}
& R_{p(t)}=\gamma_{i t}+\gamma \hat{\beta}_{1} \operatorname{LogSize}_{(t-1)}+\gamma \hat{\beta}_{2} B E / M E_{(t-1)} \\
& R_{p(t)}=\gamma_{i t}+\gamma \hat{\beta}_{1} \operatorname{LogSize}_{(t-1)}+\gamma \hat{\beta}_{2} R E / M E_{(t-1)} \\
& R_{p(t)}=\gamma_{i t}+\gamma \hat{\beta}_{1} \operatorname{LogSize}_{(t-1)}+\gamma \hat{\beta}_{2} B E / M E_{(t-1)}+ \\
& \gamma \hat{\beta}_{3} R E / M E_{(t-1)}
\end{aligned}
$$

The first model looks at the relationship between average return, log size and book-to-market risk factors. The second model looks at the relationship between average return, log-size risk factors and retained earnings-to-market. The third model looks at the relationship between average return and log-size, bookto-market, retained earnings-to-market risk factors to see how retained earnings-to-market are head to head with book-to-market.

The second method is the portfolio test using the Single Index Model approach which is a model developed from Markowitz's portfolio theory [12]. The dependent variable for this test is portfolio return arranged into six portfolios based on book-to-market ranking and retained earnings-to-market rankings based on percentile. The following model will be used for portfolio test:

$R_{p}-R f=\alpha_{i}+\beta_{p}\left(R_{m}-R f\right)+\varepsilon_{i}$ 
Table 2. Statistic Descriptive BE/ME and RE/ME (Value Weighted)

\begin{tabular}{|c|c|c|c|c|c|c|}
\hline Excess Return Portfolio & BE/ME Low & BE/ME 2 & BE/ME 3 & BE/ME 4 & BE/ME High & BE/ME H-L \\
\hline Mean & 0,000645 & 0,007539 & 0,008676 & 0,009925 & 0,02036 & 0,019718 \\
\hline Maximum & 0,3119 & 0,2175 & 0,264 & 0,1996 & 0,3153 & 0,349 \\
\hline Minimum & $-0,5364$ & $-0,2725$ & $-0,1566$ & $-0,1941$ & $-0,1874$ & $-0,2301$ \\
\hline & RE/ME Low & RE/ME 2 & RE/ME 3 & RE/ME 4 & RE/ME High & RE/ME H-L \\
\hline Mean & 0,04118 & 0,00013 & 0,002583 & 0,006593 & 0,013734 & 0,009617 \\
\hline Maximum & 0,3738 & 0,205 & 0,2674 & 0,284 & 0,1997 & 0,2953 \\
\hline Minimum & $-0,5307$ & $-0,4965$ & $-0,2668$ & $-0,1333$ & $-0,2354$ & $-0,2493$ \\
\hline
\end{tabular}

\section{RESULT AND DISCUSSION}

\subsection{Fama-MacBeth Regression}

Table 3. Fama-MacBeth Regression

\begin{tabular}{|c|c|c|c|}
\hline \multirow{2}{*}{ Factors } & \multicolumn{3}{|c|}{ Regression } \\
\cline { 2 - 4 } & $\mathbf{1}$ & $\mathbf{2}$ & $\mathbf{3}$ \\
\hline Log Size & 0,086912 & 0,104148 & 0,11164 \\
$(\mathrm{t}-1)$ & {$[1,9595]^{*}$} & {$[2,5243]^{* *}$} & {$[3,4979]^{* * *}$} \\
\hline BE/ME & $-0,13879$ & & $-0,143048$ \\
$(\mathrm{t}-1)$ & {$[-4,0124]^{* * *}$} & & {$[-3,8849]^{* * *}$} \\
\hline $\mathrm{RE} / \mathrm{ME}$ & & $-0,06545$ & $-0,065931$ \\
$(\mathrm{t}-1)$ & & {$[-3,6552]^{* * *}$} & {$[-3,4594]^{* * *}$} \\
\hline
\end{tabular}

Significant at $* * * 1 \%$

$$
\begin{aligned}
& * * 5 \% \\
& * 10 \%
\end{aligned}
$$

Table 2 represents the result of Fama-MacBeth regression from cross sectional regression (second step). Regression 1 shows that the coefficient on log size and $\mathrm{BE} / \mathrm{ME}$ are 0.086912 (significant at $\mathrm{p}$-value 10\%) and 0.13879 (significant at p-value 1\%). Regression 2 shows that the coefficient on log size and RE/ME are 0.104148 (significant at p-value 5\%) and -0.06545 (significant ar p-value 1\%). Last regression 3 that combines BE/ME and $\mathrm{RE} / \mathrm{ME}$ factors shows that the coefficient on $\log$ size, BE/ME, and RE/ME are 0.11164, -0.143048 , and 0.065931 (all significant at p-value 1\%).

Fama-MacBeth regression shows us that log size had a positive coefficient from 3 regressions; based on that result, if size of the firm increase, the return would be increase too. This result is different from Ball and Fama [4][1] the coefficient of size is negative. The explanation behind this is that when the market capitalization is calculated by market share price times outstanding shares, so when the market capitalization is increasing, it was driven by market share price.

This negative coefficient is indeed different from the results of Ball [4], but this has been predicted by Atilgan [10] that the size factor plays an important role in the variation of $\mathrm{BE} / \mathrm{ME}$ and $\mathrm{RE} / \mathrm{ME}$ and has a positive correlation between the two ratios with return. So if there is a significant change in the size, it is possible to make the two ratios decrease or increase even though there is a change in the numerator (the change in the numerator is still smaller than the change in the denominator). Based on the explanation of the FamaMacBeth regression results, it can be said that the null hypothesis is rejected, so that the retained earnings factor can explain stock returns according to the hypothesis and research results from Ball [4]. 


\subsection{Descriptive Statistics and Portfolio Test}

Table 4. Statistic Descriptive BE/ME and RE/ME (Equally Weighted)

\begin{tabular}{|c|c|c|c|c|c|c|}
\hline Excess Return Portfolio & BE/ME Low & BE/ME 2 & BE/ME 3 & BE/ME 4 & BE/ME High & BE/ME H-L \\
\hline Mean & 0,005539 & 0,008953 & 0,009456 & 0,012915 & 0,01666 & 0,00401 \\
\hline Maximum & 0,19 & 0,1213 & 0,216 & 0,2114 & 0,2219 & 0,2104 \\
\hline Minimum & $-0,3399$ & $-0,2796$ & $-0,2624$ & $-0,1973$ & $-0,1711$ & $-0,1569$ \\
\hline & RE/ME Low & RE/ME 2 & RE/ME 3 & RE/ME 4 & RE/ME High & RE/ME H-L \\
\hline Mean & 0,008163 & 0,00727 & 0,008102 & 0,010113 & 0,020026 & 0,004756 \\
\hline Maximum & 0,2216 & 0,1586 & 0,2504 & 0,1713 & 0,2198 & 0,2056 \\
\hline Minimum & $-0,3174$ & $-0,2869$ & $-0,2347$ & $-0,1949$ & $-0,2176$ & $-0,1411$ \\
\hline
\end{tabular}

Table 3 shows the descriptive statistics result for excess return portfolio sorted by book-to-market equity and retained earnings-to-market equity and formed based on value weighted. Portfolio was formed by bookto-market equity and retained earnings-to-market equity ranking. Portfolio BE/ME 1 (or low BE/ME) had an average excess return of 0.000645 , with the highest excess return of 0.3119 and the lowest excess return of 0.5364. Portfolio BE/ME 5 (or high $\mathrm{BE} / \mathrm{ME}$ ) had an average excess return of 0.02036 , with the highest excess return of 0.3153 and the lowest excess return of 0.1874. Last, portfolio 6 or BE/ME H-L had an average excess return of 0.019718 , with the highest excess return of 0.349 and the lowest value of -0.2301 .

Next are portfolio sorted by RE/ME, portfolio RE/ME 1 (or low RE/ME) had an average excess return of 0,04118 , with maximum excess return of 0,3738 and minimum excess return of -0.5307 . e excess return of 0.013734 , with highest excess return of 0.1997 , and lowest excess return of -0.2354 . Last, portfolio 6 or RE/ME H-L had an average excess return of 0.009617 , with highest excess return of 0.2953 and lowest excess return of -0.2354 . Table 4 shows the descriptive statistics result for excess return portfolio sorted by book-to-market equity and retained earnings-to-market equity and formed based on equally weighted. Portfolio was formed by book-to $\square$ market equity and retained earnings-to-market equity ranking. Portfolio BE/ME 1 (or low $\mathrm{BE} / \mathrm{ME}$ ) had an average excess return of 0.005539 , with the highest excess return of 0.19 and the lowest excess return of -0.3399 . Portfolio BE/ME 5 (or high $\mathrm{BE} / \mathrm{ME}$ ) had an average excess return of 0.01666 , with the highest excess return of 0.2219 and the lowest excess return of -0.1711 . Last, portfolio 6 or BE/ME H$\mathrm{L}$ had an average excess return of 0.00401 , with the highest excess return of 0.2104 and the lowest value of 0.1569 .

Next are portfolio sorted by RE/ME, portfolio $\mathrm{RE} / \mathrm{ME} 1$ (or low RE/ME) had an average excess return of 0,008163 , with maximum excess return of 0,2216 and minimum excess return of -0.3174 . Portfolio
RE/ME 5 (or high RE/ME) had an average excess return of 0.020026 , with highest excess return of 0.2198 , and lowest excess return of -0.2176 . Last, portfolio 6 or RE/ME H-L had an average excess return of 0.004756 , with highest excess return of 0.2056 and lowest excess retn of -0.1411 .

Table 5 representsthe result of the portfolio test using Single Index Model to see which strategy of the portfolio gives the highest alpha. On portfolio by value weighted, portfolio 1, 2, and 3 for both BE/ME and RE/ME doesn't have a significant alpha. For portfolio 4 sorted by $\mathrm{BE} / \mathrm{ME}$ had a significant coefficient of alpha 0,007639 (significant at p-value 10\%) but not for portfolio sorted by RE/ME. Portfolio 5, both sorted by $\mathrm{BE} / \mathrm{ME}$ or RE/ME, had a significant alpha of 0.017808 and 0.011219 (both significant at p-value 1\%). The last portfolio was a difference between $\mathrm{H}-\mathrm{L}$ of $\mathrm{BE} / \mathrm{ME}$, and RE/ME, portfolio sorted by BE/ME H-L had a significant alpha 0.021706 (significant at p-value 1\%) and portfolio sorted by RE/ME H-L had a significant alpha 0,015509 (significant at p-value 10\%).

Next for portfolio by equally weighted, portfolio 1 doesn't have a significant alpha. For portfolio 2 sorted by $\mathrm{BE} / \mathrm{ME}$ had a significant alpha 0,005726 (significant at $\mathrm{p}$-value $5 \%$ ) but not for portfolio sorted by RE/ME. Portfolio 3, both sorted by BE/ME and RE/ME had a significant alpha of 0,006242 and 0,004934 (both significant at p-value 10\%). For Portfolio 4 and 5, both of $\mathrm{BE} / \mathrm{ME}$ and $\mathrm{RE} / \mathrm{ME}$ alpha were significant (at pvalue $1 \%$ ), for portfolio 4 had an alpha of 0,010166 for $\mathrm{BE} / \mathrm{ME}$, and 0,007572 for RE/ME. Portfolio 5 had an alpha of 0,014045 for BE/ME and 0,017417 for RE/ME. The last portfolio was the difference between H-L of $\mathrm{BE} / \mathrm{ME}$ and $\mathrm{RE} / \mathrm{ME}$, and this portfolio doesn't have a significant alpha for both of strategy. Based on valueweighted portfolios, it is known that portfolios sorted by $\mathrm{BE} / \mathrm{ME}$ had a higher average excess return than portfolios sorted by RE/ME. From the portfolio regression test, the alpha of portfolios sorted by bookto-market is still higher than retained earningsto $\square$ market portfolios. The difference in alpha based on the HML portfolio reaches 0.010487 or $1.0487 \%$. Furthermore, based on equally weighted portfolios, portfolios sorted by RE/ME had a higher average excess 
return than portfolios prepared on the basis of BE/ME. When viewed from the results of the portfolio regression test, a higher alpha for portfolios 2, 3, and 4 was generated by portfolios sorted by book-to-market. However, in portfolio 5, a higher alpha is generated by a portfolio that is sorted by retained earnings-to-market. The average difference in excess return on portfolio 5 reaches 0.003372 or $0.3372 \%$.

Based on these results, it can be seen that there are differences between the results and Ball [4]. Ball's findings show that using value weighted results in a high average excess return and alpha on a portfolio that is structured on the basis of retained earnings-to-market. Meanwhile, in this study, when we use value weighted, it produces a higher average excess return and alpha for portfolios sorted by book-to-market. However, when we do a portfolio test using equally weighted, it produces different results. A higher average excess return and alpha are generated by a portfolio sorted by retained earnings-to $\square$ market. According to Arnott [13] this phenomenon is caused by stocks with high market capitalization which an overvalued stock, resulting in lower expected returns than stocks with low market capitalization. This is thought to result in a difference in excess return in the combination between book-tomarket and retained earnings-to-market portfolios. Based on these results, the second null hypothesis can be said to be rejected if an equally weighted portfolio is being

used.

Table 5. Portfolio Test

\begin{tabular}{|c|c|c|c|c|c|c|c|}
\hline & & Value Weighte & & & & Equally Weight & \\
\hline & Ipha & $\begin{array}{l}\text { Book-to- } \\
\text { Market }\end{array}$ & $\begin{array}{c}\text { Retained } \\
\text { Earnings-to- }\end{array}$ & & lpha & $\begin{array}{l}\text { Book-to- } \\
\text { Market }\end{array}$ & $\begin{array}{c}\text { Retained } \\
\text { Earnings-to- }\end{array}$ \\
\hline Low & $\begin{array}{c}\text { Portfolio } \\
1\end{array}$ & $\begin{array}{c}-0,003894 \\
{[-0,856699]}\end{array}$ & $\begin{array}{c}-0,000289 \\
{[-0,065094]}\end{array}$ & Low & $\begin{array}{c}\text { Portfolio } \\
1\end{array}$ & $\begin{array}{c}0,00212 \\
{[0,795438]}\end{array}$ & $\begin{array}{c}0,004788 \\
{[1,599312]}\end{array}$ \\
\hline 2 & $\begin{array}{c}\text { Portfolio } \\
2 \\
\end{array}$ & $\begin{array}{c}0,004229 \\
{[1,158747]}\end{array}$ & $\begin{array}{c}-0,003851 \\
{[-0,903744]}\end{array}$ & 2 & $\begin{array}{c}\text { Portfolio } \\
2 \\
\end{array}$ & $\begin{array}{c}0,005726 \\
{[2,110249]^{* *}}\end{array}$ & $\begin{array}{c}0,003741 \\
{[1,246806]}\end{array}$ \\
\hline 3 & $\begin{array}{c}\text { Portfolio } \\
3\end{array}$ & $\begin{array}{c}0,006366 \\
{[1,512056]}\end{array}$ & $\begin{array}{c}-0,000988 \\
{[-0,268577]}\end{array}$ & 3 & $\begin{array}{l}\text { Portfolio } \\
3\end{array}$ & $\begin{array}{c}0,006242 \\
{[1,963493]^{*}}\end{array}$ & $\begin{array}{c}0,004934 \\
{[1,704183]^{*}}\end{array}$ \\
\hline 4 & $\begin{array}{c}\text { Portfolio } \\
4\end{array}$ & $\begin{array}{c}0,007639 \\
{[1,925680]^{*}}\end{array}$ & $\begin{array}{c}0,004681 \\
{[1,192780]}\end{array}$ & 4 & $\begin{array}{c}\text { Portfolio } \\
4\end{array}$ & $\begin{array}{c}0,010166 \\
{[1,925680]^{* * *}}\end{array}$ & $\begin{array}{c}0,007572 \\
{[2,634688]^{* * *}}\end{array}$ \\
\hline High & $\begin{array}{c}\text { Portfolio } \\
5 \\
\end{array}$ & $\begin{array}{c}0,017808 \\
{[3,166539]^{* * *}}\end{array}$ & $\begin{array}{c}0,011219 \\
{[2,606679]^{* * *}}\end{array}$ & High & $\begin{array}{l}\text { Portfolio } \\
5 \\
\end{array}$ & $\begin{array}{c}0,014045 \\
{[3,309482]^{* * *}}\end{array}$ & $\begin{array}{c}0,017417 \\
{[4,167103]^{* * *}}\end{array}$ \\
\hline H-L & HML & $\begin{array}{c}0,021706 \\
{[2,954826]^{* * *}}\end{array}$ & $\begin{array}{c}0,015509 \\
{[1,845181]^{*}}\end{array}$ & $\mathrm{H}-\mathrm{L}$ & HML & $\begin{array}{c}0,004815 \\
{[1,019434]}\end{array}$ & $\begin{array}{c}0,005522 \\
{[1,114147]}\end{array}$ \\
\hline
\end{tabular}

\section{CONCLUSIONS}

This study aims to determine whether the retained earnings factor can explain stock returns in the FamaMacBeth regression test. In addition, the second objective is to compare investment strategies in the form of portfolios sorted by book-to-market and retained earnings-to-market, and can the retained earnings-tomarket strategy have higher excess returns and alpha than book-to-market. Portfolio testing using the Single Index Model with two types of weighting approaches, value weighted and equally weighted.

The results of the Fama-MacBeth regression show that the retained earnings-to-market factor can explain returns either alone or together with book-to-market. This result is consistent with the findings of Ball [4], but there are differences in the value of the coefficient on the book-to-market ratio and retained earnings-tomarket. For the second test, portfolio test results that if using value-weighted, the portfolios sorted by book-tomarket basis have higher excess return and alpha values than retained earnings-to-market. However, the results are different when the portfolio weighting uses equally weighted which results in a higher excess return and alpha for the retained earnings-to-market portfolio.

Our recommendation for further research are testing the retained earnings factor to predict return as individual stocks rather as portfolio, compare a portfolio test using Fama-French 3 Factors or Fama-French 5 Factors to see can the strategy create an alpha from the asset pricing model, and using more sample such as using ASEAN-5 stocks or Asia stocks.

\section{AUTHORS' CONTRIBUTIONS}

Muhammad Fahreza contributed on idea of research, draft, running data, analysing, and summarize. Eko Rizkianto contributed as supervisor of this research, discussion partner, and reviewing this final paper before submitted. 


\section{REFERENCES}

[1] Fama, Eugene F., and Kenneth R. French. 1993. "Common Risk Factors in the Returns on Stocks and Bonds." Journal of Financial Economics. doi: 10.1016/0304-405X(93)90023-5.

[2] Rosenberg, Barr, Kenneth Reid, and Ronald Lanstein. 1985. "Persuasive Evidence of Market Inefficiency." The Journal of Portfolio Management. doi: 10.3905/jpm.1985.409007.

[3] Basu, S. 1977. "Investment Performance of Common Stocks in Relation to Their PriceEarnings Ratios: A Test of the Efficient Market Hypothesis." The Journal of Finance. doi: $10.2307 / 2326304$.

[4] Ball, Ray, Joseph Gerakos, Juhani T. Linnainmaa, and Valeri Nikolaev. 2020. "Earnings, Retained Earnings, and Book-to-Market in the Cross Section of Expected Returns." Journal of Financial Economics. doi: 10.1016/j.jfineco.2019.05.013.

[5] Ball, Ray, Joseph Gerakos, Juhani T. Linnainmaa, and Valeri V. Nikolaev. 2015. "Deflating Profitability." Journal of Financial Economics. doi: 10.1016/j.jfineco.2015.02.004.

[6] Ball, Ray, Joseph Gerakos, Juhani T. Linnainmaa, and Valeri Nikolaev. 2016. "Accruals, Cash Flows, and Operating Profitability in the Cross Section of Stock Returns." Journal of Financial Economics. doi: 10.1016/j.jfineco.2016.03.002.

[7] Novy-Marx, Robert. 2013. "The Other Side of Value: The Gross Profitability Premium.” Journal of Financial Economics. doi: 10.1016/j.jfineco.2013.01.003.

[8] Cakici, Nusret, Sris Chatterjee, and Kudret Topyan. 2015. "Decomposition of Book-to-Market and the Cross-Section of Returns for Chinese Shares." Pacific Basin Finance Journal. doi: 10.1016/j.pacfin.2015.05.004.

[9] Blackburn, Douglas W., and Nusret Cakici. 2019. "Book-To-Market Decomposition, Net Share Issuance, and the Cross Section of Global Stock Returns." Journal of Risk and Financial Management. doi: 10.3390/jrfm12020090.

[10] Atilgan, Yigit, K. Ozgur Demirtas, A. Doruk Gunaydin, and Imra Kirli. 2020. "Decomposing Value Globally." Applied Economics. doi: 10.1080/00036846.2020.1739614.

[11] Fama, Eugene F., and James D. MacBeth. 1973. "Risk, Return, and Equilibrium: Empirical Tests." Journal of Political Economy. doi: 10.1086/260061.

[12] Markowitz, H. 1952. "Portfolio Selection Harry Markowitz." The Journal of Finance.

[13] Pae, Y., \& Sabbaghi, N. (2015). Equally weighted portfolios vs value weighted portfolios: Reasons for differing betas. Journal of Financial Stability. https://doi.org/10.1016/j.jfs.2015.04.006 